\title{
The role of relationship in moral formation: An analysis of three tertiary theological education institutions in South Africa
}

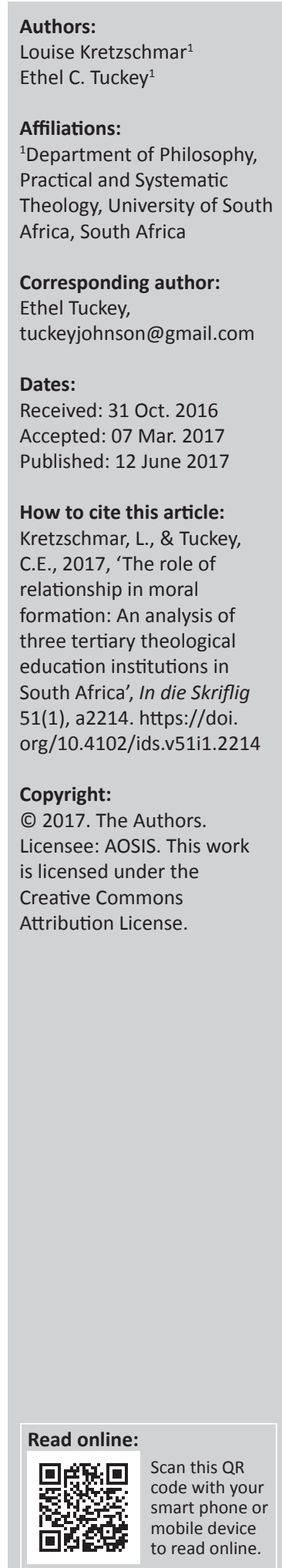

This article investigates the teaching and practice of moral formation at three theological education institutions in South Africa. Morality is described in terms of relationship with God, with the self, with others in the church and society and with the environment. Many theological institutions, while acknowledging moral formation in their aims and teaching ethical theory, have difficulty developing and implementing a moral formation programme. The findings of the research suggest that the teaching and practice at the institutions that involve relationships are most effective for moral formation. Hence it is recommended that the institutions foster the students' relationship with God, with themselves, with others and with the environment. Relational teaching methods and activities are most effective and ways of implementing them are explored, including developing partnerships with local churches.

\section{Introduction}

In a recent study on moral formation, three students, each at a different theological institution, said the following about the effects of their studies:

I now understand we are called to relate to one another, nature and God (Tuckey 2015:188).

I have had to reconsider exactly what I believe which has consequences for the way I live and the way I treat other people. Instead of reacting impulsively to issues and people, I now try to consider the whole issue. I think it has made me more compassionate (Tuckey 2015:197).

As I accept who I am (as God has made me unique), I will no longer reject myself nor strive to resemble or compete with others (Tuckey 2015:202).

These comments indicate the growing self-understanding and self-acceptance that led to deeper relationships with others, with God, and for one student at least, with nature. The stated purpose of many theological institutions is to impart knowledge, develop professional skills for ministry and enable spiritual and moral formation (Bosch 1991:16). These aims are sometimes described as 'knowing, being and doing', or 'heads, hearts and hands'. ${ }^{1}$

Theological education institutions tend to concentrate on imparting knowledge, but the professional skills and moral formation required for ministry, although vitally important, are more difficult to impart and encourage. Kretzschmar (2015:2) notes that the result is that some institutions teach about ethical theory and issues to the exclusion of moral formation. This could mean that students learn about God without really getting to know God. McGrath (1999:4) concurs that it is inadequate just to know 'about' God; it is important to know and relate to God because the Christian faith is a way of life and not just a belief system. Some students may leave theological institutions lacking in personal moral understanding and formation. They may seek to live lives of entitlement and opulence, even amongst poor struggling congregations, exploiting others and nature (Sonti 2006:32), or they may cling to a narrow legalistic understanding of God that excludes compassion and sensitivity towards others.

In the light of these challenges, this article aims to highlight the most effective modes of moral formation. In order to identify which modes of moral formation are currently used, the teaching and practice of moral formation were researched at three theological institutions: the College of the Transfiguration (COTT), St Augustine College and the South African Theological Seminary (SATS).

1.Johann Pestalozzi (1746-1827) used the "heads, heart and hands' approach which was further developed by W. von Humboldt (Jeynes 2012:178). In South Africa, outcomes based education uses the term 'heads, hearts and hands' to describe the categories of outcomes that should be achieved (Richardson 2007:147). 
The research sought to ascertain the extent to which moral formation was consciously included and pursued in the teaching and activities at these institutions and to determine which modes of moral formation had the most influence on students. This data madeit possible to make recommendations regarding the most effective ways of promoting moral formation in these theological education institutions. Such moral formation, it was hoped, would help to develop 'true disciples of Jesus' who would become agents of moral transformation, making a difference in their churches and communities. In the context of the moral crisis in South Africa, such moral formation is particularly relevant and desirable. $^{2}$

\section{What is morality?}

The concept of morality is complex, disputed and fraught with misunderstandings, especially in a postmodern world where individual choice and relativism abound. Morality is often confused with moralism and associated with a puritanical, narrow-minded, legalistic code of ethics. In this research, morality is not defined in this way, but rather seen in terms of genuine human flourishing. In the Christian context, human flourishing entails growing into the likeness of Christ, living in a Christ-like manner and bearing witness to the reign of God (Connors \& McCormick 1998:vi). This involves being in a right relationship with God, with oneself, with others and with creation. Though at times costly, these relationships are central to genuine human flourishing and encompass the personal, social and political aspects of life. To develop these relationships requires inner transformation, development of character and participation in the creative and redemptive work of God in the world and all of creation (Johnson 1989:22).

\section{Methodology: Relationship as foundational for morality}

Although researchers endeavour to be as honest and fair as possible in their investigations, their experiences and worldviews influence the way they perceive reality (Van der Ven 1994:37). In this regard, De Vos (1998:45) encourages qualitative researchers to report their approach and biases. In this particular research, the key factors and theoretical paradigms that contributed to the understanding of morality were the Bible, Christian teaching, an African and a feminist perspective and the context of the struggle for justice in South Africa. All these shaped the understanding of morality and the framework developed to research moral formation in the institutions. These factors are now briefly explained and defended.

To be fully human is to be in relationship. The doctrine of the Trinity symbolises the relational character of God as a community of equals related to each other in mutuality. Relationship is part of the very essence of God, and thus relationship is at the heart of all reality (Johnson 1992:215, 227).
Human beings are created in the Trinitarian image of God (Gn 1:26-28) and so by nature are also relational beings. As Johnson (1992:209) explains: 'The Trinity provides the ideal for a human community without supremacy or subjection, where differences flourish in the matrix of a relationship.'

There is a strong biblical imperative for a relational understanding of morality. Relationship with God was foundational for the covenant community of Israel as expressed in the command to love God with heart, soul and strength (Dt 6:5). ${ }^{3}$ Israel was to be God's people and God would be their God (Ex 6:7; Lv 26:12). From this covenant flowed relationships with others which spanned individual, social and institutional relationships (Ex 20:1-17; Dt 5:6-21). In the New Testament the centrality of relationship is affirmed through the life and teaching of Jesus. The kingdom or reign of God, which is central in the teachings of Jesus, is covenantal and its essence is the restored relationship of God with all creation (Mt 5:10, 20; Jn 3:3-5). In Jesus' teaching, the essence of the law was to love God and one's neighbour (Lk 10:27-28; Jn 13:34-35). For Jesus, remaining in relationship with God (Jn 15:1-17) was the basis for right relationships with others and all creation.

This relational emphasis also plays an important role in African moral thought as typified in the African philosophy of ubuntu (umuntu ngumuntu ngabantu); it is through others that we become fully human. Ubuntu defines a person through his or her relationships with others (Gathogo 2008:45). One exists through the fact of being known rather than because of thinking - 'I am related therefore I am', rather than 'I think therefore I am' (Bujo 2001:3; Gathogo 2008:46). ${ }^{4}$ Tutu (1989:71) affirms the concept of ubuntu saying: 'We are made for the delicate work of relationship, of interdependence. All kinds of things go horribly wrong when we break that fundamental law of our being.' Theologians such as Hauerwas (1983) and Richardson (2009) also embrace a relational perspective and stress the importance of the community in the development of moral virtues and the forming of Christian disciples.

Feminist and African Womanist theologians have stressed that a relational ethic demands respect, mutuality and equality. Thus, anything that denies or hampers the full humanity of women is not of God (Oduyoye 1995:4; Rakoczy 2004:266; Ruether 1983:19). A false image of God as a dictatorial patriarch ruling the world can reinforce patterns of domination, erroneously providing divine sanction to oppressive patterns of behaviour (Ruether 1996:3). Such beliefs, behaviour and images of God need to be challenged in order to promote mutuality between men and women and to resist the violence done to nature (Ruether 1996:3). Many feminist theologians emphasise this connection between women and nature and recognise the violence done to the natural environment and themselves (Gebara 1996; McFague 1987; Phiri 1996).

3.The account in Matthew's Gospel (Mt 22:37) includes the phrase 'and mind'.

4.For a discussion of the dangers of both individualism and communalism, see Kretzschmar (2008; 2010). 
No exposition of morality would be complete without mentioning the work of Kohlberg (1981) and Gilligan (1991). Although Kohlberg's work is mainly based on justice and abstract universal moral principles, he includes a relational element in moral decision making. ${ }^{5}$ Gilligan recognises two types of equally valid moral reasoning. One is based on an ethic of justice and rights and the other on an ethic of care and responsibility for others. ${ }^{6}$ Building on the work of Gilligan, Tronto (1993:9) recognises that an ethic of care serves both as an individual moral value and as a basis for political action for the good of society. She questions the view of morality that disregards emotions and customs in favour of distant, disengaged reasoning and abstract, formal rules. Similarly, many feminist theologians dispute the still prevalent Enlightenment view of the isolated, autonomous moral agent (Johnson 1992:68). Significantly, in the writings of the biblical prophets, for example in Micah 6:6-8, justice and mercy (care) are combined in the context of relationship with God.

Relationship is vital in individual and social life and also in moral decision making, as can be seen in the following examples. The first arises from a question posed to some organ transplant surgeons by a congenitally deformed young man in a discussion about who ought to receive an organ transplant if a choice has to be made between an able-bodied person and a disabled person (Birch \& Rasmussen 1989:58):

At first the surgeons defended their practice of excluding significantly disabled persons, all other factors being equal. They used considered, reasonable, informed and sophisticated moral and policy arguments. Yet before long they began to realise the actual consequences of their train of mind: The person who had quietly put the question to them would not, by their judgements, have been allowed to live. The surgeons experienced a kind of slow, silent moral shock. Deep down they realised they had not considered the disabled to be fully persons.

In a second example, Schluter and Lee (1993:72) illustrate the power of relationship by presenting the following scenario:

Imagine the unimaginable happened and the ATM coughed up R100 more than asked for. Would you go into the bank and give it back? Then, imagine R100 extra change being given to you in your local grocery shop. Will you return it?

The authors conclude that people are more inclined to return the money in the second instance than the first, because of the relational factor.

\section{What is moral formation?}

If morality is concerned with relationship and being at one with God, the self and others that leads to human flourishing and holistic well-being (the product), then moral formation is

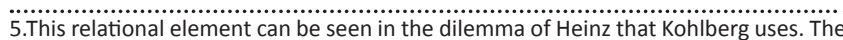
key issue is the fact that it is Heinz's wife who is dying. Without this relational connection, the dilemma loses its potency.

6. Hekman (1995:25-33) analyses the work of Gilligan and Kohlberg. She identifies the use of relation in the work of Kohlberg and further explores the ramifications of this in terms of moral theory, arguing that the many voices of relational selves belie the possibility of a single objective theory. While this discussion on moral theory goes beyond the parameters of this study, it reinforces the importance of relation as a basis for moral formation. about the methods (the process) that are used to attain this well-being. Moral formation involves growth in knowing, being and doing which together lead to moral relationships, moral living and the flourishing of humans and all creation in harmony with God.

\section{Modes of moral formation}

On the basis of this understanding of moral formation, the ways in which people are morally formed can be further investigated. In Formation of the moral self, Johannes Van der Ven (1998) identifies and discusses seven teaching and learning processes of moral formation. He terms these modes of moral formation. He identifies two informal modes (discipline and socialisation) and five formal modes that can be found in educational institutions. The five formal modes are value clarification, emotional development, transmission, cognitive development and character formation. These modes involve knowing, being and doing which are essential for a relational model of ethics. Value clarification, transmission and cognitive development all focus on the dimension of knowing. Van der Ven favours character formation which he considers to involve knowing, being and doing. In this discussion being and doing are seen as additional categories (not simply subsumed under 'character formation') because of their importance; moral formation takes place in a social and relational context.

In addition, many theologians emphasise the importance and close connection between moral formation and spiritual formation. For example O'Keefe (1995) believes:

There is no moral life separate from a spiritual life. In the actual living of the Christian life efforts to pray, to avoid sin, to make good moral decisions and to grow in virtue are all intertwined. (p. 9)

In her comprehensive book on moral formation, Charry (1997:18) asserts that 'knowing and loving God is the mechanism of choice for forming excellent character and promoting genuine happiness'. Therefore, spiritual formation, defined as knowing and loving God (and the moral actions that ought to flow from this relationship), can be conceived as an additional mode of moral formation. The means of spiritual formation include the spiritual disciplines as described by writers such as Foster (1978) in his influential book, Celebration of discipline. He categorises these disciplines in terms of an inward, a shared and an outward journey. The disciplines for the inward journey include meditation and study; the shared journey incorporates disciplines practiced as part of a faith community such as worship and guidance; and the disciplines for the outward journey include simplicity ${ }^{7}$ and service. In this the church community plays an important role. Moral formation requires community both at the conceptual and practical levels and the teaching, training and encouragement that only a moral community can provide (Richardson 2003:10). Thus, spiritual formation which includes beliefs, narratives, vision, spiritual disciplines,

7.Simplicity means, amongst other things, living without extravagance and duplicity and being actively concerned on behalf of others. 
virtuous behaviour and actions as well as friendships and relationship with God functions as an eighth mode of moral formation.

\section{Characteristics of a moral person}

The above discussion asserts that morality is essentially relational. We are embedded in relationships, and it is in loving and being loved that we become fully human. As people experience God's love and develop a relationship with God, they grow in wisdom and spiritual understanding, what Paul calls renewing of the mind ( $\operatorname{Rm~12:2;~Col~3:10).~}$ These insights and experiences of God foster the growth of a right relationship with oneself, leading to self-understanding and right relationship with others and with creation. Knowledge or wisdom combined with virtue and good actions are necessary for loving, life-giving relationships and moral living.

While the concept of relationship is central to an understanding of morality, the quality of the relationship is crucial, as not all relationships are sources of growth and joy. Some can be debilitating and destructive; therefore the characteristics of good, right and wise relationships must be explored and explicated.

As already noted, some indications of the essence and type of relationship required are found in the loving, mutual relationships that characterise the triune nature of God. The Apostle Paul identified virtues which he called the 'fruit of the Spirit' that Christians should seek to cultivate: 'love, joy, peace, patience, kindness, generosity, gentleness, faithfulness and self-control' (G1 5:22). He saw love as the most important characteristic or virtue of a Christian life (1 Cor 13:13). Jesus identified negative traits such as murder, greed, deceit, jealousy, slander and pride that make a person 'unclean' (Mk 7:21-2). Interestingly, the consensus amongst theologians regarding virtues is often more clearly revealed in the rejection of such negative qualities. Paul urges the Colossians 'to put to death' the old self with its negative traits and 'to put on' the new being which God is renewing in God's image (Col 3:1-17).

\section{A relational model of morality}

In this model five categories of relationship are considered, namely relationship with God, with the self, with others in the church, with others in society and with creation. These relationships and the role of knowing, being and doing are shown below in Figure 1 in the diagrammatic representation.

The centre of all relationships is God, so this relationship is represented by the inner oval. As we are transformed by the renewing of our mind ( $\mathrm{Rm} \mathrm{12:2)}$ and put on the new self (Col 3:10), we come to reflect the divine image (Col 3:10).

Radiating from the core relationship with God are the elements of knowing, being and doing which, while distinct from one another, work together to form moral relationships.

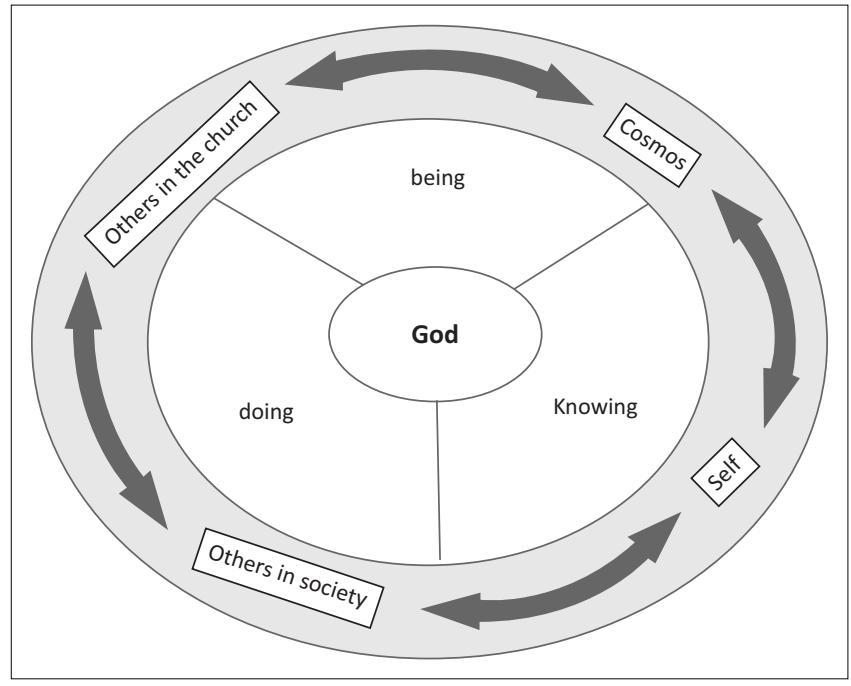

Source: Tuckey 2015:78

Figure 1: A relational model of morality.

Knowledge and understanding of norms and values inform good actions which become habits and develop good character. A person of good character, whose will is centred on the love of God and who knows what is right, performs good acts. For example a relationship of integrity requires knowledge of the truth, the will and habit of being honest and the ability to tell the truth. In the Christian context, knowledge comes from the study of and reflection on Christian norms and principles which touch every aspect of life. Paul explains to the Colossians that Christian living starts with knowledge of God that comes from wisdom and spiritual understanding (Col 3:10; 2 Pt 1:3-11).

Jesus recognised the importance of being and doing as well as knowing. He affirms that his disciples will be recognised by what they do (Jn 13:35). Christian virtues become part of one's being through their habitual practice, and this leads to moral behaviour and action (doing). Moral behaviour involves self-understanding, knowledge of what is right and wrong, will power and emotional maturity. People's relationships with the self, with others in the church and society and with creation are depicted by the outer oval.

This model was developed in the course of the research to assess the moral formation of students and certain signposts indicating moral formation were identified. The choice of the term signposts was deliberate - it indicates a direction rather than a static state of arrival. The signposts chosen were based on the relational model of morality and involved relationship with God, the self, others and the cosmos, as relationship is central to moral living. Amongst the identified signposts were a sense of awe and wonder, a desire to spend time with God, understanding and knowledge regarding Christian norms and values, selfawareness, emotional maturity, compassion, a sense of justice which leads to social action, treating people equally, knowledge of the environment and care for all creation.

The central question that this research addressed was what practices and teaching encourage moral formation. A small 
qualitative empirical study was conducted at the College of the Transfiguration, St Augustine College and the South African Theological Seminary to answer this question and confirm the theoretical research. ${ }^{8}$

\section{Explanation of the empirical methodology and data collection}

These institutions were chosen because they were representative of certain methods of education and expressions of faith. St Augustine College is a Catholic university in Johannesburg that has a Theology Department that uses face-to-face teaching as well as departments which offer other courses of study. The College of the Transfiguration is a full-time faith based residential Anglican seminary in Grahamstown, and the South African Theological Seminary is a distance learning college that makes use of written and electronic communication and describes itself as 'Biblebased, Christ-centred and Spirit-led' (SATS 2013). This choice meant that three theological traditions were represented as well as different models of theological education. A statefunded university was approached but declined to participate. The institutions were also selected on the basis of certain similarities: they are all accredited by the Council on Higher Education and involved in training for ministry, whether ordained or non-ordained.

Questionnaires were designed and administered at the three institutions. Only those senior students and staff who were willing to participate in the study did so. The questionnaires were designed to ascertain the extent to which the teaching and practice of moral formation are consciously pursued at the institutions and to investigate the teachers' and students' perception of what were the most effective teaching methods and practices for moral formation. The questionnaires clarified both the staff and students' understanding of morality and asked which modes of moral formation were used at the institution. For greater reliability, the staff's responses were compared with those of the students. Furthermore, the students identified those aspects of their theological studies that they believed had the greatest influence on their moral formation.

As described above in the model of morality, relationship is central to the understanding of morality, and the signposts indicating moral formation were linked to growth in the students' relationship with God, the self, others and the creation and formed part of the questionnaires. In connection with developing a relationship with God, the prominence given to spiritual disciplines and other practices at the theological institutions that could help students to develop a relationship with God was investigated.

The characteristics investigated in connection with relationship with the self-included emotional maturity and greater self-awareness. Did their studies give the students a deeper understanding of their faith and help them to make ethical decisions?

8.The study was done between 2013 and 2014 .
In terms of relationship with others, the research investigated whether deepening their spirituality and experience of God led the students to a greater concern for justice and care for the poor and vulnerable. Were students engaged in service to those in need? Could they critique society and analyse political and social structures in the light of the gospel? Were they aware of the need for Christian involvement at a structural level such as lobbying government to provide basic necessities for all and to allocate resources to uplift the poor? Could students link this awareness to an understanding of the prophetic role which challenges socio-political and economic injustices that oppress and exploit the weak? Could they recognise and challenge patriarchal practices?

Care for and knowledge of the environment tend to be linked, so knowledge of the environment and evidence of care for life-sustaining systems and all living creatures that share the planet with us was investigated.

\section{Findings from the data}

Many students believed that their relationship with God had grown. For example a student from St Augustine College felt that she had a far deeper understanding of the trinitarian nature of God (Tuckey 2015:195). Another was 'more convinced that God acts when I pray and that this action might often be God asking me to act' (Tuckey 2015:195). 'I have deepened my relationship with God and look forward to spend time with Him every day', affirmed another (Tuckey 2015:189).

The students' relationship with their inner self had also grown. This transpired partly through increased knowledge and understanding, so a student could debate using arguments based on concrete evidence, rather than just on the basis of personal opinions. This increased knowledge and awareness led the student to 'think twice before I do anything' (Tuckey 2015:189). Another student commented that she was 'challenged to think more deeply and consciously about issues and to recognise the complexity surrounding moral issues' (Tuckey 2015:196). Another student believed his studies had helped him 'to explore the fundamentals of who I am and why we are here' (Tuckey 2015:196).

In terms of relationship with others, a student from COTT realised that morality was not just personal. Initially he thought that 'Christianity is about individualism and going to heaven' rather than about community. 'I now understand that we are called to relate with one another, nature and God' (Tuckey 2015:188). A St Augustine student linked her growth with others to her relationship with God. She learnt that 'praying together is a necessity' and from this she became more involved in the church's ministry to those in need. She added, 'I choose to be hurt rather than to hurt others' (Tuckey 2015:197). A student from SATS felt that his studies had 'played a part in the values I practice in my community' and he now treated car guards and those who live on the street with kindness and interest (Tuckey 2015:203). The teaching of environmental ethics at the institutions led to some students 
becoming more aware that morality involved care for the environment. However, facts about the environment were seldom taught at any of the institutions.

The aspects of their studies that the students considered the most influential were assessed in the light of Van der Ven's seven modes of moral formation, along with the mode of spiritual formation. Insights from these modes formed part of the research and were thus inherent in the development of the relational model of morality.

Not surprisingly, the transmission and cognitive modes of formation were most frequently used as these are educational institutions where the teaching of moral knowledge is important. However, these modes were most effective for moral formation when used in a relational manner. For example a student comments (Tuckey 2015):

My interaction with students and lecturers has been a gift to me that has taught me much about life. I feel rich to have been given this opportunity to study theology. (p. 171)

This was the comment of a student from COTT who had the opportunity to be part of a residential community. Six of the seven students from St Augustine affirmed group discussion and interaction with lecturers as being significant. The fact that we 'were encouraged to work through issues, examining our own beliefs and feelings rather than simply giving answers that we thought were the right ones' was important (Tuckey 2015:170). Similarly a student from SATS found being mentored by a staff member very influential.

In particular group discussions, the encouragement of critical thinking, reflection and mentoring from staff members, all of which involve interaction with others and therefore relationship, contributed to the students' moral formation. This correlates with Van der Ven's (1998) view of the centrality of relationship:

Character does not unfold from within the person in isolation, but is called out through interaction with others in the situation and through grappling with tasks and challenges that are part of that situation. (p. 354)

Students found ethical theory most helpful when taught in conjunction with the use of inspiring stories and case studies which recounted people's experiences and awakened imagination and moral vision. This included the Christian story and their personal stories. Ethical theory, while important to know, appeals to the head, and the students felt it had limited influence on their moral formation, unless it was taught in a way that engaged their hearts. ${ }^{9}$ The students found the concept of 'what would Jesus do' helpful, despite the complexity of interpretation from biblical times to the modern context. It appeared that imitation of Jesus appealed to their hearts as well as their heads, as it involves building a relationship with Jesus. As a student commented, 'I grow in self-knowledge as I understand God better' (Tuckey 2015:190). Other educators such as Dube (2003) have documented the helpfulness and relevance of stories as a means for reflection on social systems and oppression.

Other practices that the students identified as important for their moral formation included decision-making methods, explaining and relating Christian doctrines to their lives, exercises that encouraged self-knowledge and value clarification. Of particular importance for moral formation was the encouragement of and opportunity for students to be involved in human struggles and with the poor. 'Study projects in the community made me more aware of the teachings in scripture on helping the poor', said a student (Tuckey 2015:203). This finding is corroborated in the Iona document (Amirtham \& Pyor 1989) which notes that involvement in the harsh realities of life and situations of human struggle can lead to spiritual growth. ${ }^{10}$

Growing spiritually was considered important by the participants, but how this is to be achieved was less clear, particularly for those students studying at a distance as they could not attend worship together or share times of meditation and discussion. In a residential setting such as that of COTT, times of worship, celebration and silence are possible. These were helpful, but a more comprehensive spiritual and moral formation programme is needed. This finding regarding the rather sporadic focus on spiritual formation fits with research carried out in other seminaries by Naidoo (2011). She found that conscious, clear spiritual formation programmes were lacking in the institutions she studied. ${ }^{11}$

From the responses of the staff and students, it emerged that the modes of moral formation least used were character formation and emotional development. Students felt that they were not helped to be more aware of their feelings. While the head, heart and hands are often mentioned in education, the actual cultivating of the heart, of emotions and of moral virtues may be overlooked.

Relationship was the thread that ran through the responses of the students as the most influential for moral formation. By comparing the responses from the staff and the students with existing theoretical research regarding moral formation, several recommendations for moral formation can be made.

\section{Recommendations}

Relationships with God, the self, others and creation are interlinked. As one grows in one of these relationships, one is likely to grow in the others as well. For example a student commented that 'her spirit jumped for joy at all she learnt' (Tuckey 2015:196). Knowing more about God can lead to a changed lifestyle. The students saw the moral implications of a deeper understanding of and growing relationship with God. Another example is a student that changed from

10.This document was drawn up by a number of theological educators who met a lona in Scotland to discuss ways of spiritually empowering those training for various ministries in the church.

11.These institutions were all full-time residential institutions. 
thinking of God as 'the Father who is there to meet my needs to the Father who is to be respected, obeyed and loved'. He felt that his lifestyle had 'become less selfish' (Tuckey 2015:196). The recommendations are discussed below in terms of the different relationships, keeping in mind that they are interrelated.

\section{Help students to develop a deeper relationship with God}

Moral formation and spiritual formation go hand in hand, therefore ways of deepening the relationship with God need to be found. This could be achieved through a more conscious and sustained use of the spiritual disciplines. The inner and corporate disciplines such as prayer, meditation and worship are quite easily included in a full-time residential environment. It is more challenging to find ways of including them in part-time and distance education settings, but course material could include teaching on the importance of silence, meditation and other spiritual disciplines, followed up by assignments that require students to journal and report on their practice of the disciplines.

Relationship with others is important, and thus there should be teaching about the outer disciplines such as service and simplicity. The shared disciplines such as worship and celebration should also be part of the programme. This is not always possible in distance education, therefore partnerships with local churches are important for helping students to practice these disciplines and grow as disciples. More formal and deliberate partnerships between the churches and the theological education institutions should be developed. The role of the church community, worshiping and working together is widely recognised as important for moral formation, and students should be encouraged to be part of a faith community (Hauerwas 1975). Amongst other things, this could require students to do projects and assignments in their local churches. This could help them to make the connections between study, spiritual growth and action.

\section{Developing a relationship with the self}

Journaling and reflection on what is being taught are ways of developing the self-understanding which is so important in moral formation. Music and the arts could be explored as methods of educating the heart, of touching emotions and thereby forming character. Other relational modes of learning such as discussing, meditating on or dramatising stories from the Bible and the students' own stories can be incorporated in the study process as they appeal to the heart as well as the head.

Scholarly study, when done in an interactive way, can open new vistas for the students and give them greater selfunderstanding, deeper insight into their faith and more understanding of the implications of ethical teaching for their lives. Group discussions, challenging case studies and mentoring by staff members are all part of this journey and contribute to moral formation. They help students to relate ethical theories to their context and concerns. Importantly, what is learnt is not only of academic interest but may also make a difference to the way the students live.

\section{Developing relationship with others}

Students should be exposed to situations of need which can encourage the practice of virtues so that they become habits and a way of life. The fact that students at COTT were encouraged to become involved in projects with the local churches is an example of how this could be done. In a distance learning institution, assignments could require students to be involved in community projects. Visits to local NGO projects, a prison, orphanage, refuge for battered women, or a hospital can be arranged. Such visits need to be followed up with reflection on and an analysis of their experiences of the harsh realities of life. Students' own experiences and exposure to those of others can help them to develop an awareness of oppression, a prophetic ministry and the moral courage to confront issues of injustice.

Teaching Christian norms and values should enable students to critique their culture and society and challenge them to reflect on their assumptions and to be open to new ideas. Opportunities need to be created to encourage students to reflect on social justice and discern biblical themes and teaching in this regard. As relationship is central to morality, relationships of respect for all are crucial. This means that care and compassion for those in need and standing up for what is right and just should be central to what is taught and practiced. Further, attention to the situation of women is important, therefore institutions should use gender inclusive language and include feminine as well as masculine images of God.

The most influential modes of moral formation involved relationships; theological institutions should thus foster relationships between staff and students and between fellow students. Time can be made for mentoring and to develop friendships with other students, for example through the facilitating of study groups. For students studying in distance education settings, the local church could help to identify suitable mentors. Electronic communication such as e-mail, WhatsApp or telephone conferencing can be used to keep in contact. The concept of blended or block education can be explored by part-time and distance learning institutions. This involves students coming to the institution for a block of time which allows opportunities to spend time with others in, for example seminars, lectures, workshops, worship and meditation. If such block learning times are difficult to organise at the institution, partnerships could be formed with the local churches to provide such opportunities. These could be mutually beneficial for the churches and students.

\section{Relationship with creation}

If care of creation is to be given more than lip service by the institutions, students need to learn about the environment, to understand the forces that cause destruction of the environment and to gain some knowledge of the world 
around them. Recognising the limited time for 'scientific studies', DVDs or TV programs could be used to create awareness. Visits to existing projects that allow for exposure and awareness as well as encouraging the students' own involvement could be organised.

Knowledge of the environment is important if people are to start caring for it. At institutions where students physically attend lectures, activities such as vegetable growing, saving energy and recycling can be practiced. Assignments that involve getting to know about and care for the environment can be required as part of their theological studies.

\section{Conclusions}

The findings showed that an emphasis on moral formation is found in all the institutions where the research was conducted, but not always in a very conscious and systematic manner. While the institutions do recognise the importance of relationship, in practice, they focus mainly on cognitive development, imparting knowledge and practical skills for ministry, using teaching and practices that do not necessarily or consciously foster relationships. Further, the findings indicated that modes of moral formation involving relationships with God, the self and others had the greatest influence on students' moral formation. Teaching and practices that involve relationships such as mentoring, tutoring, group discussions, the use of stories, building self-esteem, emotional awareness, meditation and prayer should be deliberately devised and used in theological education. Partnerships with local churches can be beneficial for both the church and the institution and should beencouraged. What can be done and how the recommendations can be implemented will depend on each institution. However, the fact that there were so many commonalities regarding the importance of relationship for moral formation leads to the conclusion that despite the differences, modes of moral formation that build relationship are most effective.

\section{Acknowledgements Competing interests}

The authors declare that they have no financial or personal relationships which may have inappropriately influenced them in writing this article.

\section{Authors' contributions}

The research upon which this article is based was conducted by E.C.T. during the writing of her doctoral thesis. L.K. was her supervisor for this thesis. L.K. and E.C.T. contributed equally to article.

\section{References}

Amirtham, S. \& Pryor, R., (eds) 1989, Resources for Spiritual Formation in Theological Education, WCC Programme on Theological Education, Geneva.

Birch, B.C. \& Rasmussen, L.L., 1989, Bible and ethics in Christian life, Augsburg, Minneapolis.

Bosch, D.J., 1991, 'The nature of theological education', Journal of Theology for Southern Africa 77, 3-17.

Bujo, B., 2001, Foundations of an African ethic, Crossroad, New York.
Charry, E.T., 1997, By the renewing of your minds, Oxford University Press, Oxford.

Connors, R.B. \& McCormick, P.T., 1998, Character, choices and community: The three faces of Christian ethic, Paulist Press, New York.

De Vos, A.S. (ed.), 1998, Research at grassroots, Van Schaik, Pretoria.

Dube, M.W., 2003, 'Social location as a story-telling method of teaching', in M.W. Dube (ed.), HIV and AIDS and the curriculum: Methods of integrating HIV and AIDS in theological programmes, pp. 101-112, WCC Publications, Geneva, viewed 22 theological programmes, $\mathrm{pp}$. 101-112, $\mathrm{CCC}$ Publications, Geneva, viewed 22
February 2013, from http://www.wcc-coe.org/wcc/what/mission/dube-10.html

Foster, R., 1978, Celebration of discipline, Hodder \& Stroughton, London.

Gathogo, J., 2008, 'African philosophy as expressed in the concepts of hospitality and ubuntu', Journal of Theology for Southern Africa 130, 39-53.

Gebara, I., 1996, 'The Trinity and human experience', in R.R. Ruether (ed.), Women healing earth, pp. 13-23, SCM, London.

Gilligan, C., 1991, 'Women's psychological development: Implications for psychotheory', in C. Gilligan, A. Rogers \& D. Tolman (eds.), Women, girls and psychotherapy: Reframing resistance, pp. 5-31, Harrington Park Press, New York.

Hauerwas, S., 1975, Character and the Christian life: A study in theological ethics, Trinity University Press, San Antonio.

Hauerwas, S., 1983, The peaceable kingdom: A primer in Christian ethics, University of Notre Dame Press, Notre Dame.

Hekman, S.J., 1995, Moral voices, moral selves, Pennsylvania State University Press, University Park.

Jeynes, W. (ed.), 2012, International handbook of Protestant education, Springer, New York.

Johnson, E.A., 1992, She who is: The mystery of God in feminist theological discourse, Crossroad, New York.

Johnson, S., 1989, Christian spiritual formation in the church and classroom, Parthenon, Nashville.

Kohlberg, L., 1981, Essays on moral development, vol. 1, The philosophy of moral development: Moral stages and the idea of justice, Harper \& Row, New York.

Kretzschmar, L., 2008, 'Christian spirituality in dialogue with secular and African spiritualities with reference to moral formation and agency', Theologia Viatorum 32(1), 63-96.

Kretzschmar, L., 2010, 'Cultural pathways and pitfalls in South Africa: A reflection on moral agency and leadership from a Christian perspective', Koers 75(3), 567-588.

Kretzschmar, L., 2015, 'The education of prospective ministers as an invitation to life: Moving from moral failure to moral excellence through a process of moral formation', In die Skriflig 49(1), Art. \#1868, 1-10. https://doi.org/10.4102/ ids.v49i1.1868

McFague, S., 1987, Models of God: An ecological theology, Fortress, Minneapolis.

McGrath, A., 1999. Christian spirituality, Blackwell, Malden.

Moagi, D., 2002, Moral regeneration framework, South African Government discussion document, Department of Arts, Culture, Science and Technology.

Naidoo, M., 2011, 'An empirical study on spiritual formation at theological training institutions in South Africa', Religion and Theology 18(4), 118-146. https://doi. org/10.1163/157430111X61369

Oduyoye, M.A., 1995, Daughters of Anowa: African women and patriarchy, Orbis Books, Maryknoll.

O'Keefe, M., 1995, Becoming good, becoming holy: On the relationship of Christian ethics and spirituality, Paulist Press, New York.

Phiri, I.A., 1996, 'The Chisumphi cult: The role of women in preserving the environment', in R.R. Ruether (ed.), Women healing earth, pp. 161-171, SCM, London.

Rakoczy, S., 2004, In her name: Women doing theology, Cluster, Pietermaritzburg.

Richardson, N., 2003, 'Not another moral summit: Problems and possibilities for moral regeneration', Scriptura 82, 3-14. https://doi.org/10.7833/82-0-893

Richardson, N., 2007, 'Ministerial training in theological education in the Methodist Church of Southern Africa: The road ahead', Missionalia 35(2) 131-152.

Richardson, N., 2009, 'Morality and community', in L. Kretzschmar, W. Bentley \& A. van Niekerk (eds.), What is a good life? An introduction to Christian ethics in 21st century Africa, pp. 43-56, Academy SA, Kempton Park.

Ruether, R.R., 1983, Sexism and God talk: Towards a feminist theology, SCM, London. Ruether, R.R., 1996, Women healing earth, SCM, London.

SATS, see South African Theological Seminary

Schluter, M. \& Lee, D., 1993, The R factor, Hodder \& Stroughton, London.

Sonti, M.V., 2006, 'Economic justice and ministry for a change', TEE Journal, 6, 29-34.

South African Theological Seminary, 2013, About the South African Theological Seminary, viewed 21 June 2013, from http://www.sats.edu.za/about-us/

Tronto, J., 1993, Moral boundaries: A political argument for an ethic of care, Routledge, New York.

Tuckey. E.C., 2015. 'An ethical investigation of the teaching and practice of moral formation at St Augustine College, the College of the Transfiguration and the South African Theological Seminary', (Unpublished DTh thesis), Department of Philosophy, Practical and Systematic Theology, University of South Africa.

Tutu, N., 1989, The words of Desmond Tutu, Hodder \& Stoughton, London.

Van der Ven, J., 1994, 'Empirical methodology in practical theology: Why and how?', Practical Theology in SA 9(1), 29-44.

Van der Ven, J.A., 1998, Formation of the moral self, Eerdmans, Grand Rapids. 